\title{
Haiti, MINUSTAH e democracia: a técnica de governo biopolítico na operação da Organização das Nações Unidas
}

Lukas Lobo Santos ${ }^{1}$

\begin{abstract}
Resumo: Este trabalho tem por objetivo analisar a Missão das Nações Unidas para a Estabilização do Haiti (MINUSTAH) como um mecanismo de governo biopolítico e continuidade da prática, por parte das nações tidas como grandes potências ocidentais, de intervenção nos processos políticos haitianos desde sua Independência, em 1804. Para isto, realizamos análise bibliográfica acerca do tema, bem como análises de documentos da Organização das Nações Unidas, de instituições envolvidas na operação e do governo brasileiro. Abordando os conceitos elaborados por Michel Foucault, o trabalho apresenta as diferentes técnicas de governo - como racismo de Estado, dispositivo de polícia e disciplina - utilizadas pelos países estrangeiros nas intervenções no Haiti, ao longo dos séculos XIX, XX e início do XXI, para impor valores democráticos liberais, prescrever condutas ao Estado haitiano e aos indivíduos. Ademais, apontamos os interesses do Brasil em comandar a face militar da MINUSTAH.
\end{abstract}

Palavras-chave: MINUSTAH. Biopolítica. Racismo de Estado.

\section{Haiti, MINUSTAH and democracy: the technique of biopolitical government in the United Nations operation}

\begin{abstract}
This work proposes to analyze the United Nations Stabilization Mission in Haiti (MINUSTAH) as a mechanism of biopolitical government and continuity of practice by nations considered to be major western powers to intervene in Haitian political processes since their independence, in 1804. For this end, we developed a bibliographical analysis on the subject, as well as analysis of documents of the United Nations and other institutions involved in the operation and the Brazilian government. By approaching the concepts elaborated by Michel Foucault, the work presents the different techniques of government - such as state racism, police device, and discipline - used by foreign countries in interventions in Haiti, during the
\end{abstract}

\footnotetext{
${ }^{1}$ Licenciado em História pela Universidade do Estado do Rio de Janeiro (UERJ) e pesquisador no projeto "Subjetividade e política no campo da infância e da juventude" (UERJ/CNPq). Pesquisador das relações de poder, racismo de Estado e biopolítica no Brasil e na América Latina. Endereço: Rua Joaquim Salvador, 10, Mutuá. São Gonçalo/RJ. Email: lobolukkas@gmail.com.
} 
nineteenth and twentieth centuries, to prescribe conducts to the Haitian state and individuals. In addition, we point out the interests of Brazil in commanding the military face of MINUSTAH. Key words: MINUSTAH. Biopolitics. State racism.

Artigo recebido em: 26/11/2019

Artigo aprovado para publicação em: 27/03/2020

\section{Introdução}

O Haiti tem sua história marcada por lutas internas complexas e intervenções externas. Buscando compreender sua especificidade no contexto das Missões da ONU, desenvolveremos uma análise sobre a história recente do país a partir da Revolução (1791-1804) - entendida por nós como determinante para orientar os processos que constituíram o país posteriormente.

Ao conquistar a independência pela luta de negros escravizados e livres, no início do século XIX, o país caribenho passou a estabelecer relações diplomáticas com um Ocidente ainda baseado no escravagismo. Tratava-se, portanto, de um país negro enfrentando o desafio de ser efetivamente reconhecido como independente em uma dinâmica de poder com países que, até então, se beneficiavam - direta ou indiretamente - da exploração da mão-de-obra negra escravizada.

Da experiência de fundar uma nação de negros livres, o Haiti enfrentou diversas disputas internas e sofreu várias invasões que levaram o historiador haitiano Pierre-Charles (2004, p. 31) a afirmar que a comunidade internacional está sempre a postos para intervir, com seu fuzil de ombro, nos processos políticos do país. Desde a Independência (1804), a ilha sofreu com o isolamento diplomático imposto pelas ditas potências ocidentais durante o século XIX: foi invadida e ocupada pelos fuzileiros estadunidenses (1915-1922), teve uma cruel ditadura civilmilitar financiada pelo governo dos EUA (1957-1986) e foi ocupada outras vezes pela ONU durante seu processo de redemocratização, nos anos de 1990, até que, por fim, a MINUSTAH foi estabelecida em 2004.

Devido a isso, este trabalho se propõe a analisar a MINUSTAH como o ápice, e a continuidade da prática de intervenções externas nos processos políticos haitianos desde sua Independência utilizando de diferentes técnicas de governo para intervir na conduta dos 
indivíduos e do próprio Estado. Para tanto, realizaremos análise de bibliografias relativas ao tema, como também de documentos das Nações Unidas e de instituições envolvidas na operação.

O trabalho encontra-se dividido em três grandes seções. Na primeira estabelecemos uma breve apresentação dos casos de intervenção externa ao longo da história do Haiti - da Independência à MINUSTAH - fazendo uso principalmente da historiografia haitiana. Ademais, apontamos a emergência, na Europa do século XVIII, do que Michel Foucault denomina de nova razão governamental cujo objeto é a população, entendida como técnica de governo. O racismo de Estado e a polícia são outras ferramentas do autor utilizadas nesta seção para analisarmos as intervenções externas.

$\mathrm{Na}$ segunda seção, dissertamos sobre os dispositivos de segurança que também emergem dessa nova razão governamental e possibilitam a criação de organizações diplomáticas multilaterais. A partir disso, apresentamos a fundação da Organização das Nações Unidas e o contexto da segurança humana no qual a MINUSTAH está inserida. Enquanto que na última seção, apresentamos um breve histórico da diplomacia brasileira e analisamos os interesses que motivaram o país a comandar o aparato militar da operação.

\section{HAITI: A Revolução (1791-1804)}

A Revolução Haitiana, no fim do século XVIII e início do XIX, que conquistou a independência pelas mãos de negros escravizados e livres, é fundamental para a história do Ocidente contemporâneo. Embora não tenhamos a pretensão de realizar neste trabalho uma análise aprofundada da revolução, dada sua complexidade política e racial, partiremos para uma breve apresentação dos fatos.

A Ilha de São Domingo, como até então era conhecido o Haiti, envolvia diretamente a presença de três continentes: a Europa, representada pela França como a principal exploradora do território, a África, de onde vinha a mão-de-obra escravizada, e a América, evidentemente, continente da Ilha. Identificar tal relação triangular é importante para compreender a dimensão 
do significado histórico da Revolução do Haiti. Como aponta Castor (2004, p. 18), foi no Haiti que os descendentes de africanos iniciaram o processo de independência dos povos latinoamericanos do colonialismo branco europeu.

Às vésperas da revolução, a ilha contava com cerca de 500 mil escravizados, 28 mil libertos e 40 mil brancos, além de receber anualmente de 25 a 30 mil negros africanos. Ademais, como primeiro produtor de açúcar do mundo, o Haiti rendia aos franceses lucros parecidos aos que a América espanhola proporcionava à Espanha. Organizados em uma sociedade muito complexa, a relação com a França se tornava cada vez mais conflituosa no decorrer do século XVIII. Com a presença dos ideais iluministas circulando pela Ilha - quando da tomada da Bastilha (tradicional prisão de Paris), em 1789, por exemplo, ao menos dois personagens diretamente ligados a São Domingos estavam presentes, sendo eles o abade Henri Grégoire e o colono Monreau de Saint-Mery ${ }^{2}$ - as reivindicações cresciam. Os brancos reclamavam maior autonomia frente à metrópole, os libertos pediam igualdade cívica em relação aos brancos, os escravizados organizavam inúmeras resistências - que naquele momento, dada a brutalidade do trabalho, tinham vida útil de apenas sete anos - além do jogo de influência de potências interessadas na instabilidade da Ilha como Inglaterra e Espanha.

Embora inspirados pelos ideais iluministas, é importante demarcar a distância que os negros tinham, em suas lutas e princípios, dos revolucionários franceses, uma vez que estes últimos não questionavam (muito menos enfrentavam) a realidade da escravidão ${ }^{3}$ e da colonização. Aliás, muitos desses revolucionários não só negligenciavam como também apoiavam a manutenção de ambas. Por isto, “como já assinalara o historiador C.R.L. James, foi [...] a Revolução do Haiti que forçou a Revolução Francesa a levar adiante, efetivar e

\footnotetext{
${ }^{2}$ Uma análise sobre tais personagens pode ser encontrada em: Abade Grégoire e os escravos: fraternidades e Luzes in: MOREL, Marco. A Revolução do Haiti e o Brasil escravista o que não pode ser dito. Jundiaí: Paco, 2007.

${ }^{3}$ As elaborações da Revolução Francesa acerca da igualdade entre os seres humanos e o direito à liberdade, contida na Declaração dos Direitos do Homem e do Cidadão (1789), não foram abrangidas aos negros escravizados. Além de alguns líderes defenderem a escravidão e aboli-la só após a Revolução do Haiti, a Revolução Francesa (1789), por exemplo, estabeleceu o sufrágio, em 1792, mas excluiu mulheres e pessoas de baixa renda - entre os que se destacavam os negros, obviamente. O sufrágio universal masculino só foi concebido em 1793, porém, revogado em 1795, um ano após a abolição, retornando aos quesitos censitários - para ser eleitor era necessário comprovar determinada renda e ter propriedade de terra. Ou seja, suas concepções de cidadão partiam do ideal de homem branco.
} 
universalizar a defesa dos propalados direitos do homem" (MOREL, 2017, p. 86). Quando a França abole a escravidão em suas colônias, em 1794, esta já não existia mais em São Domingos, destruída a partir das lutas de escravizados, libertos e livres. Ademais, na França do século XVIII que Foucault afirma (2008, p. 56), em seu curso "Segurança, território e população", emergir a nova razão de Estado que tem por objeto e objetivo a população. Para tanto, o autor utiliza-se do exemplo da gestão da escassez de cereais, na França do mesmo século.

De acordo com Foucault (2008, p. 42), para impedir a escassez, o governo francês vai estabelecer uma série de proibições (como exportações, aumento do preço e estocagem) por meio de um sistema jurídico-disciplinar a fim de manter o preço mais baixo possível. Todavia, a fixação dos preços gerará menor salário e diminuição dos lucros dos camponeses, fazendo com que estes abandonem o cultivo e a escassez retorne. A partir de então, o governo francês adota um método parecido com o inglês, que estabelece certa liberdade de circulação dos cereais, prevendo a possibilidade de exportação de trigos e cereais em períodos de boa safra (para que o preço não desabe devido à abundância), ao mesmo tempo em que impõe algumas taxas de importação para evitar que uma grande compra também faça os preços caírem.

Os fisiocratas, no início do século XVIII, pregando a liberdade total de circulação (de exportação, importação e estocagem) analisaram os fenômenos coletivos e individuais que envolvem o comércio e a produção de cereais, tais como abundância/escassez e carestia/preço baixo, apoiando-se nessa realidade, não para tentar impedir previamente a escassez, mas para, por meio do dispositivo de segurança, limitá-la e anulá-la.

Enquanto a disciplina delimita um espaço para que seu poder funcione plenamente, regula tudo para impedir que os fenômenos aconteçam e estabelece o que é permitido e proibido. O dispositivo de segurança se apoia nos detalhes, considerando os processos necessários por estarem no nível da população. Além disso, o dispositivo de segurança não trabalha a partir da perspectiva do obrigatório e do proibido ou para complementar a realidade, mas trabalha na própria realidade para regulá-la. Ou seja, o que a formulação econômicopolítica dos fisiocratas torna pertinente é a população, e não a multiplicidade dos indivíduos como no sistema disciplinar. 
Em São Domingos, na década de 1780, inúmeras rebeliões protagonizadas por escravizados emergiram, entretanto, sempre brutalmente reprimidas com suplícios e execuções públicas. No verão de 1790 , mulatos ${ }^{4}$ foram linchados em praça pública ao reivindicarem direitos políticos. Vicent Ogé, um mulato, vai à França para tentar articular os mesmos direitos dos brancos aos seus iguais, porém, sem sucesso, retorna e organiza grupos armados. Os escravizados, por sua vez, começam a protagonizar as lutas revolucionárias com uma rebelião em Platon, em janeiro de 1791, sob a liderança de Jean-Baptiste Perrier. Já em agosto de 1791, ocorre a cerimônia do bosque Caïman, na qual cativos se reuniram sob a liderança de Bouckman, escravizado jamaicano e sacerdote vodu ${ }^{5}$ que convocou todos os escravizados à sublevação geral (MOREL, 2017, p. 89). Segundo Castor,

Um braseiro ardente prendeu e arrastou os escravos. Estes rechaçaram o deus dos brancos e invocaram seus deuses que lhes ordenavam através do sacerdote vodu Boukman "koute la libete, ki pale nan kè nou" (escutem a liberdade que fala em seus corações) para consagrar a legitimidade do direito à rebelião e à insurreição. (CASTOR, 2004, p. 19).

O processo revolucionário, inicialmente, contou com apoio dos espanhóis aos grupos de negros ${ }^{6}$ e mulatos, visando enfraquecer o domínio francês na região. Os espanhóis chegaram a formalizar a aliança em 1793. Os brancos colonos locais, por sua vez, aliaram-se aos ingleses. Nesse período, Inglaterra e Espanha haviam declarado guerra contra a França após a morte de Luís XVI. Entretanto, ao abolir a escravidão, em 1794, a França consegue o apoio dos escravizados e derrota as tropas espanholas. Após superar as divergências dos grupos internos nos primeiros anos do processo revolucionário, Toussaint Louverture (1743-1803), o principal líder da revolução, torna-se Governador Geral de São Domingos e principal autoridade da colônia, nomeado pela Revolução Francesa, em 1796 - ano, inclusive, em que a Inglaterra proíbe o tráfico de negros africanos. Segundo Castor (2004, p. 20), Toussaint, o "estadista

\footnotetext{
${ }^{4}$ Denominação dada aos negros livres remediados financeiramente.

${ }^{5} \mathrm{O}$ vodu foi um dos pilares e uma forma de unificação dos grupos revolucionários. Conforme Fick (2014, p. 104112), a religião, bem como as culturas de origem africana, ao impulsionarem o protagonismo dos trabalhadores escravizados, foi um dos elementos fundamentais na luta revolucionária.

${ }^{6}$ Denominação dada aos trabalhadores escravizados.
} 
genial", retirou do território as tropas inglesas e espanholas, montou o aparato militar, reestruturou a economia, além de ter articulado a autonomia de São Domingos frente à metrópole.

Em 1802, Napoleão Bonaparte envia tropas com cerca de 20 mil homens à Ilha. Embora os negros oferecessem resistência, com a liderança de Dessalines (1758-1806) - outro importante líder revolucionário - foram derrotados e Toussaint preso. Com a vitória, Napoleão decreta o retorno da escravidão em São Domingo, medida que impulsionou, no mesmo ano, uma insurreição com a união de vários grupos de negros e mulatos liderados por Dessalines, Cristophe (1767-1820) e Pétion (1770-1818). Em 1803, as tropas francesas, completamente derrotadas e com a morte de seu general, evacuam a Ilha: o confronto deixou cerca de 60 mil mortos de ambos os lados (MOREL, 2017, p. 109). Em janeiro de 1804, a independência haitiana é proclamada formalmente e Dessalines, um ex-trabalhador escravizado, se autoproclama Imperador. Os últimos franceses que viviam na Ilha foram mortos nos anos seguintes.

A questão racial permanece como elemento fundamental, assim como foi durante toda a revolução, na construção do novo Estado. Embora tenha alternado entre república e monarquia durante o século XIX, as duas primeiras Constituições do Haiti abordam a questão racial no que se refere ao direito à propriedade de terras e cidadania. Destaco, entretanto, a primeira Constituição, promulgada em 1805, que se refere a todos os haitianos como negros, explicitando o pertencimento racial e rompendo com o ideal branco do citoyen iluminista. Além disso, conforme Morel (2017, p. 124), as primeiras Constituições apontam para a formação de uma aristocracia social e política negra e mulata.

Os desafios de ser reconhecido como um país independente e constituído por negros, estabelecendo relações diplomáticas com vizinhos escravistas, impôs ao Haiti contradições e sanções cobradas pela França como, em 1825, a redução de 50\% das tarifas alfandegárias às importações francesas e uma indenização de 150 milhões de francos - valor que equivalia a toda receita anual do Haiti multiplicada por dez - e caso o governo haitiano não aceitasse tais medidas, o país seria cercado por tropas francesas. O Haiti, então, fez empréstimos com bancos franceses, estadunidenses e alemães com enormes taxas de juros que fez com que essa divida se arrastasse até 1947, 122 anos depois, ano da última parcela (BBC, 2019, p. 1). 
Foucault, em seu curso "Em defesa da sociedade", dado no College de France, entre 1975 e 1976, estuda, dentre outras coisas, um novo discurso histórico que emerge durante o século XVI. Esse discurso é vinculado a uma percepção e a uma repartição binária da sociedade e dos homens entre justos e injustos, ricos e pobres etc. A emergência desse discurso, o discurso sobre a luta das raças, foi um marco para o fim da Antiguidade. Entretanto, afirma Foucault (2005, p. 94) que tal discurso é retomado por outra função a partir do século XIX, não mais pelo sentido da guerra histórica - de dois grupos com suas batalhas e invasões -, mas pelo sentido biológico da luta pela vida. O Estado, por meio do racismo de Estado, toma o poder sobre o homem enquanto ser vivo.

Nesse contexto, o racismo é inserido nos mecanismos do Estado pelo biopoder e tornase o principal mecanismo de intervenção do poder sobre a vida. O racismo possibilita o corte entre quem deve viver e quem deve morrer, fragmentando, no interior de uma população, uns grupos em relação a outros. Ademais, estabelece-se entre a vida de uns e a morte de outros não uma relação militar - da guerra -, mas uma relação biológica, pois a morte da raça inferior é o que deixará a vida mais saudável. Ou seja, o biopoder, por meio do racismo garante a função assassina do Estado.

A multa e as sanções impostas pela França representaram um assassínio indireto à ilha recém-independente impondo-lhe a exclusão e o isolamento político e econômico. Para Castor,

\footnotetext{
O novo Estado teve que se defender dos projetos de reconquista dos franceses, contornar as intenções de domínio da Inglaterra, recorrer a uma diplomacia com uma América do Norte escravista, e lutar para que se reconheça o direito de existir. Além do inexorável castigo que foi o cordão sanitário imposto pelas maiores potências à jovem nação. (CASTOR, 2004, p. 21).
}

O medo de um colapso do regime escravista nas Américas se tornou cada vez maior após a independência haitiana. Morel (2017, p. 258-274) apresenta o caso do Dr. Meirelles, um cirurgião mulato que discordou da orientação de separar pacientes negros e brancos na Santa Casa, Rio de Janeiro, em 1829. A crítica do cirurgião resultou em inúmeras publicações de periódicos temendo a "força negra", mostrando a preocupação dos letrados da época com a já terminada Revolução do Haiti e exemplificando o que a historiografia denominou de 
haitianismo. Apesar de ser um caso específico do Brasil, os grandes centros ocidentais não possuíam perfis antagônicos a este. O grande número de escravizados presente no fluxo dos centros urbanos, a circulação dos ideais iluministas e a proibição do tráfico atlântico de escravizados também caracterizavam esses centros ocidentais, à época do Dr. Meirelles, cujo haitianismo era presente.

\title{
Ocupação dos fuzileiros navais dos EUA (1915-1934)
}

Para compreendermos as novas técnicas de governo do sistema de segurança em um contexto internacional - que incidem sobre o Haiti -, mobilizaremos Foucault (2008, p. 421), que apresenta a polícia como um instrumento próprio da nova arte de governar. $\mathrm{O}$ autor define polícia, a partir do século XVII, na Europa, como o conjunto dos meios que fazem as forças do Estado crescer ao mesmo tempo mantendo a boa ordem desse Estado. Ao possibilitar que as forças do Estado cresçam, a polícia trata diretamente com o problema do equilíbrio entre os Estados europeus:

\begin{abstract}
A manutenção do equilíbrio só é adquirida na medida em que cada um dos Estados é capaz de fazer crescer sua própria força e numa proporção tal, que ele nunca seja superado por outro. Só se pode efetivamente manter a balança e o equilíbrio na Europa na medida em que cada um dos Estados tenha uma boa polícia que lhe permita fazer suas próprias forças crescerem. (FOUCAULT, 2008, p. 423).
\end{abstract}

Entretanto, se o crescimento não for similar, haverá um desequilíbrio. Por isso,

\begin{abstract}
Chegaremos rapidamente à consequência, de certo modo paradoxal e inversa, que consistirá em dizer: mas, afinal, se no equilíbrio europeu há um Estado, mesmo que seja o meu, que tenha uma má polícia, vamos ter um fenômeno de desequilíbrio. Por conseguinte, é preciso zelar para que, mesmo nos outros Estados, a polícia seja boa (FOUCAULt, 2008, p. 423).
\end{abstract}

Analisando a formulação de polícia de Turquet de Mayerne, Foucault (2008, p. 431) aponta que o principal objeto desse instrumento é a atividade dos homens como elemento constitutivo da força do Estado. A polícia utilizará todo instrumento para dar utilidade estatal às atividades dos homens. Com isso, o autor elenca cinco objetos da polícia: primeiro, o número de homens, pois é preciso saber a quantidade e fazer que esta cresça; segundo, as necessidades 
da vida (alimentação, por exemplo), pois é preciso fazer com que esses homens vivam; o terceiro, o problema da saúde, já que a saúde é o que torna possível que tais homens trabalhem; o quarto, zelar pela atividade dos homens, para colocá-los para trabalhar e atender as demandas do Estado e zelar pelas diferentes atividades que cada um possa exercer; o quinto, a circulação de mercadoria, assim, cuidará das rodovias, da navegabilidade dos rios, canais etc. O filósofohistoriador conclui:

\begin{abstract}
De maneira geral, no fundo, o que a polícia vai ter de regular e que vai constituir seu objeto fundamental são todas as formas, digamos, de coexistência dos homens uns em relação aos outros. É o fato de viverem juntos, de se reproduzirem, de necessitarem cada um de seu lado, de certa quantidade de alimento, de ar para respirar, viver, subsistir, é o fato de trabalharem, de trabalharem uns ao lado dos outros, em ofícios diferentes ou semelhantes, é também o fato de estarem num espaço urbano de circulação. (FOUCAULT, 2008, p. 437).
\end{abstract}

Em permanente estado de vigilância e implicado pela polícia, as intervenções das grandes potências ocidentais no Haiti ocorrem ao longo de todo o século XX. Os EUA, emergente potência capitalista, invade e ocupa a Ilha entre os anos de 1915 e 1930. Segundo Castor (2016, p. 62), as décadas anteriores à invasão foram marcadas pela intensificação na disputa entre a burguesia emergente e os latifundiários no país, além de as rivalidades interimperialistas terem repercussão na política nacional. Em 1879, a burguesia, de maioria mulata, fundou o Partido Liberal e organizou uma expedição para derrubar o Partido Nacional, então representante do setor latifundiário. No entanto, o governo conseguiu manter-se e frustrar o êxito da expedição. Em 1888, a Marinha estadunidense apoiou a insurreição de militares do norte do Haiti contra o governo central, também derrotada. Em 1908, há outra tentativa de tomada de poder pela burguesia contra o então Presidente Nord Alexis (1902-1908), dessa vez apoiada pela França, porém, novamente derrotada pelo exército.

Após resistir às insurreições, Nord Alexis terminou seu mandato dando continuidade ao processo eleitoral e, após isso, entre 1908 e 1915, deu-se um período bastante agitado politicamente: foram sete governos em sete anos - três deles derrubados por insurreições. Em 1915, o pressuposto utilizado para a ocupação estadunidense - que durou dezenove anos - foi uma nova insurreição que ocasionou a morte de 173 presos políticos. Durante a ocupação, os EUA se preocuparam em dar um caráter legal estabelecendo uma autoridade nativa, para isso 
nomearam Sudre Dartiguenave (1915-1922) e Louis Borno (1922-1930). A organização administrativa haitiana foi completamente modificada, o poder legislativo - senado e câmara dos deputados - foram dissolvidos e substituídos por um Conselho de Estado, nomeado e revogado pela vontade do Presidente. O judiciário foi oprimido e perdeu autonomia. A elite local, que havia apoiado a ocupação inicialmente, passou a se sentir prejudicada. Com a ocupação, começaram a pagar impostos - o que não faziam antes -, foram desprezados das relações comerciais e impedidos de assumir cargos públicos, além de serem tratados pelos estadunidenses como país conquistado e raça inferior. Segundo Castor (2016, p. 90), desde a Independência, os haitianos, e principalmente a elite, não haviam sofrido discriminação racial nem experimentado nenhum sentimento de inferioridade.

O governo de Dartiguenave esteve completamente alinhado aos princípios dos EUA sua pré-disposição a isso foi também um fator para que fosse nomeado presidente. Usou os fuzileiros navais estadunidenses para reprimir violentamente as resistências e protestos contrários à ocupação, além de ter sancionado leis para limitar a liberdade de oposição. Mesmo com seu alinhamento quase automático, Dartiguenave se opôs aos EUA na questão monetária, em 1920. Um projeto de lei elaborado nos EUA pelos representantes do Departamento de Estado proibia que qualquer importação ou exportação fosse efetivada em moeda não haitiana sem a autorização prévia do Conselho Financeiro - nomeado pelos EUA - pois, segundo os estadunidenses, tal medida asseguraria a independência do sistema monetário haitiano. Dartiguenave não sancionou o projeto, e como retaliação o então conselheiro financeiro John Mcllhenny suspendeu o salário do presidente e seus ministros. Ao reclamar com o presidente dos EUA, Dartiguenave recebeu a orientação de aprovar quatro leis como prova de sua cooperação com os EUA, dentre elas a modificação do estatuto do Banco Central haitiano e a transferência desse estabelecimento para o National City Bank $k^{7}$. Essas medidas foram aceitas pelo presidente do Haiti, todavia, geraram aumento da pressão política interna (CASTOR, 2016, p. 95).

\footnotetext{
${ }^{7}$ Banco norte-americano. 
O governo de Borno, por sua vez, foi de incondicional apoio aos Estados Unidos. O exministro de Dartiguenave foi saudado no fim de seu governo pelo então comandante dos fuzileiros estadunidenses John Russell, por não haver tomado jamais nenhuma decisão sem antes tê-lo consultado. Foi o momento em que a ocupação teve menos resistência em relação ao governo. Entretanto, houve mobilização popular dividida entre lutas armadas e protestos pacíficos contrários à ocupação, segundo Castor (2016, p. 98).

Conforme a Constituição de 1918, o Conselho de Estado deixaria de existir em 1930 e as eleições parlamentares aconteceriam novamente. Porém, em 1929, Borno iniciou uma campanha para a manutenção do Conselho de Estado e do regime político de cooperação com os EUA. Com apoio dos oficiais estadunidenses no Haiti, Borno lança uma circular anunciando a manutenção do Conselho de Estado e a crise política se instala. A oposição se organizou para derrubar a medida do governo e a insatisfação popular toma as ruas de todo o país. Juntamente a isso, surge uma nova política nos EUA com o recém-eleito presidente Hoover (1929-1933), que entende a retirada dos fuzileiros do Haiti como a melhor saída para a crise política (CASTOR, 2016, p. 184). Com a crescente das manifestações e a organização política da população, Borno anunciou que não se reelegeria, e alguns meses depois os EUA retiraram as tropas de fuzileiros do país.

Ainda segundo Castor (2016, p. 63), a invasão estrangeira alterou as bases do processo político impondo uma estrutura social e política ao Haiti, que impediu a continuação da disputa política local mais do que ajudou em seu crescimento enquanto Nação. Ao contrário, tal ocupação marcou uma estratégia intervencionista dos Estados Unidos nos países do Caribe e da América Latina durante todo o século XX. Segundo a autora, a guerra contra a Espanha pelo controle de Cuba em 1898 representou um giro imperialista na política externa dos EUA:

América Latina, e em particular a zona do Caribe, ocuparam um lugar seleto dentro dessa estratégia de conquista. Com suas terras tropicais, ricas e férteis, sua densa população, o "mediterrâneo americano" era considerado por muitos estadistas norteamericanos como um proibido particular. "É inevitável que, mais cedo ou mais tarde, os Estados Unidos protejam e regulamentem a vida nas Repúblicas do Caribe" comentava Theodore Roosevelt. (CASTOR, 2016, p. 43). 
Depois da guerra e ocupação em Cuba (1898), os EUA ainda intervieram em diferentes países da América Latina antes de invadirem o Haiti em 1915. Essa estratégia se atualiza, sob novas justificativas, no apoio estadunidense aos inúmeros regimes ditatoriais que se estabeleceram na América Latina. Entre 1934 e 1957, os EUA permaneceram exercendo influência política e econômica no Haiti, atingindo seu ápice na ditadura da família Duvalier.

\section{Ditadura (1957-1986)}

Em 1957, François Duvalier, "Papa Doc", chega à presidência do Haiti após um turbulento processo eleitoral com inúmeras denúncias de fraudes. Desde o início de seu governo, Duvalier adotou práticas de repressão e controle das instituições: no exército, trocou generais e oficiais; universidades e imprensa foram suprimidas; até mesmo a Igreja Católica teve bispos afastados pelo então presidente. Em mais uma intervenção externa, os EUA prontamente ofereceram aporte financeiro, político e militar a Duvalier para obterem apoio na sua luta anticomunista - Eisenhower, então presidente dos EUA, chegou a elogiar o presidente haitiano publicamente. Já em 1958, uma equipe de fuzileiros da marinha estadunidense foi destacada ao Haiti para oferecer treinamento ao exército local, em contrapartida, Duvalier ofereceu uma base militar para o lançamento de mísseis. O apoio financeiro do governo estadunidense passou de US\$ 1 milhão no início da década de 1960 - no contexto da Guerra Fria $^{8}$ e pós-Revolução Cubana ${ }^{9}$. Em mais uma prática autoritária, Duvalier fundou sua própria milícia, em 1962, conhecida como Corpo de Voluntários da Segurança Nacional. A ditadura de fato se estabeleceu quando, em 1964, o presidente convocou um referendo constitucional que fez de seu mandato vitalício, com poder absoluto e o direito de nomear seu sucessor - o resultado de $99,9 \%$ favoráveis e 0,01\% contrários também levantou denúncias de fraudes (CAJOU, 2013, p. 29).

\footnotetext{
${ }^{8}$ Disputa político-econômica travada pela conquista de zonas de influências entre EUA e URSS iniciada após a Segunda Guerra Mundial (1939-1945) e chegando ao fim no início dos anos 1990.

${ }^{9}$ Movimento político que destituiu o ditador Fulgêncio Batista e instaurou o regime socialista liderado por Fidel Castro.
} 
A conduta extremamente violenta da ditadura era combinada com a extrema pobreza do país. A expectativa de vida era de 34 anos, a escolarização chegava a apenas 16,5\% das crianças e a renda per capita não passava dos US\$ 63 (CAJOU, 2013, p. 31). Além da sua milícia organizada, Duvalier utilizava-se também dos "Tontons Macoutes", um grupo de matadores que se colocavam a serviço do governo para exercerem poder em determinadas regiões. Um dos casos emblemáticos da violência desse regime foi o massacre à cidade de Jeremie, onde várias famílias foram sumariamente assassinadas (PIERRE-CHARLES, 1973, p. 83). Com a morte de Duvalier, em 1971, seu filho, "baby doc", assume com o apoio da burguesia branca e mulata, e dos EUA, para garantir-lhe a transição (CAJOU, 2013, p. 35). O herdeiro da presidência não alterou as bases políticas de seu pai, como também não conseguiu modificar a dura realidade econômica e social do país. A partir de 1977, com a retirada do apoio de parte da burguesia, assim como com a reestruturação dos setores sociais, iniciou o processo de decadência do regime. Entretanto, sem se adaptar ao processo de uma transição lenta como algumas ditaduras da América Latina, conforme aponta Castor (1986, p. 61), Jean Duvalier reprimiu ainda mais a oposição.

Em 1984, a mobilização popular toma as ruas pela primeira vez desde o início da ditadura:

A mobilização popular vai muito além dos gritos de "abaixo a fome" e "abaixo Duvalier" com que as massas expressavam suas queixas e repúdio à ditadura. Pela primeira vez em 27 anos o povo tomou às ruas, vencendo o terror, o medo, a desorganização e desafiando os Tontons Macoutes e toda a sofisticada máquina de matar da ditadura. (PIERRE CHARLES, 1984, p. 18).

A instabilidade política aumentou e, em janeiro de 1986, o povo vai às ruas novamente em um grande protesto. Os quartéis dos Tontons Macoutes foram destruídos, as casas dos dirigentes da ditadura foram incendiadas e barricadas foram levantadas nas ruas. Segundo Castor (1986, p. 55), os EUA já não mais conseguiam sustentar o ditador e estavam sendo duramente criticados no cenário internacional. Jean Duvalier, então, sem conseguir asilo político em nenhum país, partiu em um avião da força aérea estadunidense para a França, de onde renuncia e estabelece um Conselho Nacional de Governo de seis membros, dando início à transição democrática. 


\section{Da redemocratização à MINUSTAH}

O processo de redemocratização que se abrira não foi menos turbulento que as décadas anteriores. Em 1990, Jean Aristides vence a eleição presidencial, pelo partido comunista, com amplo apoio popular. Todavia, já no ano seguinte sofre uma tentativa de golpe organizada por setores do exército que o obrigou a se exilar por três anos nos Estados Unidos, onde preparou seu retorno articulando forças com os EUA e a ONU. Ao retornar, segundo Pierre-Charles (2004, p. 32), Aristides contou com o investimento de 1 bilhão de dólares para utilizar em projetos sociais e, com a presença de vinte mil soldados da ONU, instalava-se a Missão das Nações Unidas no Haiti (UNMIH) - que tinha por objetivo garantir o retorno de Aristides.

Em uma análise no calor dos acontecimentos, Castor (1995, p. 9) aponta que essa presença estrangeira modifica a conjuntura local:

\footnotetext{
Vinte mil soldados estrangeiros em um território pesam muito. Sob o mandato do artigo 940 da ONU, essa força militar - majoritariamente estadunidense desembarcou em Porto Príncipe em setembro de 1994. Sejam quais forem as considerações referentes à gênese e as principais modalidades da intervenção, esta "Missão para Democracia", adquire um peso específico importantíssimo na conjuntura e na evolução futura da situação. (CASTOR, 1995, p. 9).
}

Devido à sua má gestão, a segunda fase do governo de Aristides comprometeu ainda mais a economia, ao mesmo tempo em que não se abriu politicamente para atrair outras categorias sociais. No governo de seu sucessor e apadrinhado político, René Preval, a preocupação de Suzy Castor com a evolução da situação citada anteriormente se justifica. Após sucessivas derrotas por uma oposição organizada, o então presidente manda dissolver o parlamento, em 1998, sob o suporte da Missão de Polícia Civil das Nações Unidas no Haiti (MIPONUH) (PIERRER-CHARLES, 2004, p. 34). Entre a UNMIH e a MIPONUH ainda houve outras duas intervenções da ONU: a Missão de Suporte das Nações Unidas no Haiti (UNSMIH), com o objetivo de promover a reconciliação nacional, e a Missão de Transição das Nações 
Unidas no Haiti (UNTMIH), que substituiu a última e teve como objetivo formar os policiais haitianos.

As eleições legislativas e presidenciais do ano 2000 aprofundam ainda mais a crise política. Aristides, eleito novamente, recrudesce sua política de impor o executivo ao legislativo com o objetivo de monopolizar o Estado a seu serviço, como explica Pierre-Charles (2004, p. 39). Esse cenário de crise política é objeto de análise de Antonin (2006, p. 1), que entende que a crise haitiana é, na verdade, uma sucessão de crises eleitorais. O autor, que publica seu artigo "La enesima crisis electoral" no auge de uma eleição, já na MINUSTAH, afirma que em todas as eleições após a redemocratização, principalmente após o retorno do presidente Jean Aristides do exílio, o país vive tensão e há denúncias de manipulação de resultado.

O ano de 2003 foi marcado pela aglutinação de setores progressistas e de massas populares na oposição ao então presidente Aristides - conforme Pierre-Charles (2004, p. 36). Pedindo a queda do presidente, em 2004, os setores políticos pretendiam realizar as eleições e ocupavam as ruas com grande apoio popular, sendo intensamente reprimidos pela polícia e grupos paramilitares. Aristides renunciou e seu sucessor, presidente da Suprema Corte, pediu auxílio imediato à ONU, que respondeu com o estabelecimento da MINUSTAH.

Tal histórico de invasões, para Pierre-Charles (2004, p. 31), aponta que as grandes potências ocidentais estão sempre atentas e prontas para corrigir qualquer sinal de desordem no território haitiano. Entre 1994 e 2004, a ONU instalou-se em território haitiano com cinco missões diferentes, interferindo, alterando e interrompendo o processo político local.

\section{ONU: da fundação à proposta de missão permanente no Haiti}

Tratando da racionalidade governamental e da guerra na transição para a modernidade, em "Segurança, território e população", Foucault (2008, p. 383-449) apontará algumas características do sistema de segurança. Segundo o autor, a partir do século XVI, as rivalidades dinásticas entre príncipes, na Europa, transformam-se em rivalidades - ou concorrência - entre Estados quando da emergência de uma nova razão governamental. Nessa relação de 
concorrência, a guerra entre Estados é tratada não mais pela expansão territorial ou pelo aumento de alianças matrimoniais, mas pelo aumento da força do Estado. Essa nova racionalidade se ocupa de conservar a correlação de forças entre os Estados.

A gestão da relação de forças é observada por Foucault (2008, p. 398) no Tratado de Vestefália, pois este foi elaborado no sentido de manter o equilíbrio entre os Estados. Era necessário administrar a correlação de forças ao mesmo tempo em que permitisse o crescimento de cada uma delas sem comprometer o conjunto, o que Foucault (2008, p. 398) definiu como função do dispositivo diplomático-militar. Ou seja, da gestão do equilíbrio entre os Estados emergiu a balança européia: mecanismo que garantia a impossibilidade de o Estado mais forte impor suas leis a qualquer outro, e preservava um arranjo no qual a força do maior Estado não fosse superior a de todos os outros juntos.

Ao contrário de uma escatologia universal, de um Império absoluto de dominação sobre os demais Estados, surge, para Foucault (2008, p. 402), uma escatologia relativa e frágil: a paz. Não mais dependendo de uma supremacia absoluta (Império e Igreja), a paz é esperada da pluralidade dos Estados. A guerra, explica o autor, torna-se o primeiro instrumento da frágil paz. A partir disso, o autor aponta algumas transformações que ocorrem na função, justificativa e pensamento jurídico do uso da guerra nesse contexto. Na Idade Média, a guerra acontecia devido a uma injustiça, uma violação do direito ou quando alguém pretendia um direito contestado por outro. A guerra medieval estava, sobretudo, no campo do litígio - na liquidação do litígio. Todavia, a guerra passa a funcionar de outra maneira, deixando de tratar do litígio para ser uma relação política, de razão de Estado, com o objetivo de evitar o desequilíbrio de forças e o retorno do Império:

No fundo, já não é necessário alegar uma razão jurídica para deflagrar uma guerra. Tem-se perfeitamente o direito de alegar, para deflagrar uma guerra, uma razão puramente diplomática - o equilíbrio está comprometido, é necessário restabelecer o equilíbrio, há um excesso de poder de um lado e não se pode tolerá-lo (FOUCAULT, 2008, p. 404).

Além da guerra, outro instrumento fundamental ao equilíbrio interestatal é o instrumento diplomático. Os diplomatas vão transferir territórios, negociar, trocar cidades e 
seguir linhas jurídicas determinadas pela necessidade de um equilíbrio. Nesse momento, surge o Tratado de Vestefália, um tratado multilateral que tratará dos conflitos na totalidade dos Estados que constituem a Europa.

O último instrumento desse sistema diplomático-militar é o estabelecimento de um dispositivo militar permanente que comportará a profissionalização do homem de guerra - uma carreira das armas -, uma estrutura armada permanente capaz de suprir as tropas em tempo de guerra, um equipamento de fortalezas e transportes, assim como um saber de táticas militares. Esse é um dos instrumentos indispensáveis ao equilíbrio europeu.

A polícia, instrumento já apresentado, faz parte de um segundo grande conjunto tecnológico distinto dos três apontados anteriormente (guerra, diplomático e militar) que compõem o sistema diplomático-militar. Um instrumento comum à polícia e ao dispositivo diplomático-militar, que passou a articulá-los, é a estatística. Para que o equilíbrio seja mantido na Europa, os Estados precisam conhecer suas forças e as forças dos outros Estados, além de estabelecer uma comparação para acompanhar e manter o equilíbrio. Por meio da estatística, cada Estado ficará ciente, de si e dos outros, sobre os recursos naturais, capacidade do exército, tamanho de sua população, produção, comércio, circulação monetária etc. Para Foucault (2008, p. 424), a estatística não só se torna necessária por causa da polícia, como também se torna possível por causa da polícia.

Como um desdobramento do dispositivo diplomático-militar e da polícia, surge a Organização das Nações Unidas, após o fim da Segunda Guerra Mundial, ainda no mesmo ano, em outubro de 1945, tendo como principal objetivo a manutenção de segurança e paz no contexto internacional do pós-guerra. Segundo Ribeiro (2004, p. 60), o ensaio para a formação da ONU acontece ainda durante a Segunda Guerra com a elaboração da Declaração de Moscou assinada por URSS, EUA, Reino Unido e, posteriormente, China. Em reunião realizada nos EUA, em 1943, os países visavam estabelecer na Declaração as bases para fundamentar a Organização. Entre os dias 25 de abril e 26 de junho de 1945, ainda no decorrer da Guerra, ocorreu a Conferência Internacional em São Francisco, nos EUA, a qual resultou no documento fundador da ONU que vigoraria a partir de outubro daquele mesmo ano. URSS, EUA e Reino Unido foram protagonistas da Organização. 
A fundação da ONU inaugurou um novo cenário nas relações entre Estados. Buscando a manutenção de um determinado conceito de paz e segurança internacionais, a Organização Nações Unidas elaborou o sistema de segurança coletiva e o aperfeiçoou, acompanhando as complexidades do contexto em que esteve inserido. O Haiti foi objeto dessas novas ferramentas para aplicar tal sistema.

Tratando-se principalmente de um sistema de segurança coletiva ${ }^{10}$ - noção elaborada anteriormente na Sociedade das Nações ${ }^{11}$ - para a manutenção da paz internacional, a Carta de São Francisco é composta por 111 artigos com os principais objetivos comuns aos seus signatários. Segundo Corbellini (2009, p. 62), a Carta estabelece e faz constante referência ao Conselho de Segurança, órgão das Nações Unidas cuja atribuição é implementar o sistema de segurança coletiva e garantir a manutenção da paz e segurança internacionais. O Conselho é composto por quinze Estados-membros, dos quais cinco são permanentes.

Apesar de erguer-se tendo a paz enquanto princípio, Rodrigues (2013, p. 140) aponta que a possibilidade da guerra não esteve descartada na política externa dos signatários da ONU, ainda que como autodefesa ou defesa coletiva. Ademais, conforme Rodrigues (2013, p. 135), a partir do curso "Segurança, Território e População", Foucault afirma que o dispositivo diplomático-militar sofreu poucas alterações em comparação ao dispositivo de polícia. Considerando ainda que a emergência da governamentalidade neoliberal indique grandes transformações nas práticas de governo da população, se o dispositivo diplomático-militar não sofreu alterações entre o século XVII e XX, o mesmo não se pode dizer no período posterior a Segunda Guerra Mundial (1937-45). Anteriormente a isso, a própria expansão napoleônica, as experiências anarquistas e socialistas, a Comuna da Paris (1871), a formação de novos Estados e o avanço colonial sobre os Estados africanos fizeram com que os Estados Europeus ensaiassem novos arranjos para adequar o equilíbrio. Rodrigues (2013, p. 138) explica que

\footnotetext{
${ }^{10}$ Sistema que regulamenta o emprego da força (entre Estados), desenvolvendo um procedimento para substituir o uso da força e organizar a ação comum contra o agressor. Devido ao poder de veto - prerrogativa que impunha o consenso entre os membros permanentes do Conselho - o Conselho de Segurança esteve impossibilitado de aplicar o sistema de segurança coletiva das Nações Unidas durante a Guerra Fria, pois EUA e URSS representavam interesses opostos.

${ }^{11}$ Organização internacional fundada pelos países vencedores da Primeira Guerra Mundial em Versalhes, em 1919, com o objetivo de estabelecer a paz internacional.
} 
ocorreu uma reformulação do direito à guerra, na segunda metade do século XIX, que se voltou à regulamentação - calcada por valores humanitários - da fabricação e do emprego de armas tidas como cruéis. Conferências diplomáticas de cunho humanitaristas foram convocadas, juntamente com a formação de organizações privadas humanitaristas como a Cruz Vermelha (1863). Segundo o autor, essa nova codificação da guerra tem o objetivo de torná-la mais "humana". Impor limitações à violência na guerra pode ser visto como uma tentativa de conter o emprego de avanços tecnológicos próprios da produção capitalista, ou seja, o humanitarismo foi um movimento de atualização do dispositivo diplomático-militar, pois equipara as forças militares dos Estados no espaço de concorrência.

O surgimento de organizações multilaterais permanentes, como a Liga ou Sociedade das Nações, em 1918, de acordo com Rodrigues (2013, p. 140), foi caracterizado pela nova concepção da guerra entendendo-a enquanto instrumento de defesa e como reguladora do sistema internacional quando praticada coletivamente contra um Estado que violasse a soberania de outro (regra estabelecida em Vestfália). Tal concepção permanece na fundação da ONU quando o humanitarismo toma mais centralidade a partir da Declaração Universal dos Direitos do Homem (1948). Segundo o autor, a Declaração é um marco fundamental da articulação entre uma antiga e uma emergente configuração do dispositivo diplomático-militar, pois o "Homem" passa a ser o sujeito a ser protegido por cada Estado.

A partir do início dos anos 1990, inúmeros problemas - como a segurança alimentar, segurança ambiental e segurança energética - para o governo das pessoas passam a ser incorporados nos discursos diplomático-militares dos Estados e nos discursos da ONU como ameaças a segurança dos Estados, no plano individual, e a estabilidade internacional (Rodrigues, 2013, p. 142). Porém, a segurança humana é o conceito fundamental, segundo o autor, para compreendermos a mudança no campo da segurança internacional que passa a indicar o "homem" como o sujeito a ser protegido. Rodrigues explica que:

Nesse contexto, a segurança do Estado não teria sido superada, mas recondicionada à segurança humana, o que articularia de modo inédito uma dimensão universal - os direitos humanos - a um elemento particularista, a segurança de cada Estado. Ademais, a segurança de todo o sistema de Estados passaria a depender do respeito 
aos direitos humanos, o que propiciou o despontar de um redimensionamento importante da justificativa para ir à guerra a partir dos anos 1990: a intervenção humanitária. (RODRIGUES, 2013, p. 142).

O conceito de Responsabilidade de Proteger (ou R2P), desenvolvido em 2001, surge para possibilitar, no âmbito das intervenções humanitárias, a preservação da centralidade do Estado e da segurança do Estado, ao mesmo tempo em que propõe transformações para gerir problemas internacionais. Elaborada para determinar que cada Estado tenha a obrigação de proteger o que se entende por direitos humanos de seus cidadãos, a R2P foi aprovada pela Assembleia Geral da ONU como um dos princípios da Organização. Apesar de não possuir caráter mandatório, segundo Rodrigues (2013, p. 143), o conceito tem sido mobilizado para justificar as intervenções humanitárias. Ou seja,

O conceito de R2P foi apresentado como um modo não de suplantar a regra da inviolabilidade da soberania estatal - proveniente da formação do sistema de Estados - mas de redimensioná-la introduzindo um elemento de valoração para seu exercício: um juízo sobre o bom ou mau exercício da soberania. (RODRIGUES, p. 143, 2013).

A partir da obra de Gareth Evans ${ }^{12}$, Rodrigues (2013, p. 146) aponta outros dois pilares da R2P que são fundamentais para o governo da paz: a responsabilidade prevenir, que tem o objetivo de solucionar os conflitos desde as raízes; e a responsabilidade de reconstruir, cujo objetivo é reconstruir aquilo que a intervenção foi destinada a interromper. Para o autor, tais elementos produzem "modelos de conduta que tornam uma soberania má ou boa, bem ou mal exercida" (RODRIGUES, 2013, p. 146). E a democracia liberal está dentre as práticas qualificadas como um bom exercício de soberania. Rodrigues formula, então, a emergência de um dispositivo diplomático-policial:

As sanções policiais - no sentido da polícia apenas como força repressiva surgida no século XIX, como indicou Foucault (2008) $)^{13}$ - seriam apenas um dos aspectos de um novo dispositivo de segurança planetário que não prescinde da dimensão diplomáticomilitar, mas que se articula a ela conectado à defesa de valores universais ao mesmo

\footnotetext{
${ }^{12}$ Ex-Ministro das Relações Exteriores da Austrália.

${ }^{13}$ FOUCAULT, Michel. Segurança, território, população. São Paulo: Martins Fontes, 2008.
} 
tempo em que não abandona, mas redimensiona a segurança dos Estados (agora, conectada à segurança humana) (RODRIGUES, 2013, p. 151).

Ou seja, o "dispositivo de polícia, em sua característica de regulamentação minuciosa das condutas seria, nessa hipótese, atualização da regulação, anunciando a emergência de um dispositivo de segurança planetário" (Rodrigues, 2013, p. 152) que seria o dispositivo diplomático-policial.

As novas ferramentas de manutenção da paz $^{14}$ das Nações Unidas atingem estruturas para além da dimensão militar. As novas missões de estabilização estarão comprometidas em construir uma cultura política voltada aos valores democráticos liberais e na criação de instituições como os três poderes constitucionais, a polícia etc.

Requerida formalmente pelo governo haitiano, a MINUSTAH foi autorizada pelo Conselho de Segurança da ONU por meio da Resolução 1542 (2004) e com base no Capítulo VII ${ }^{15}$ da Carta das Nações Unidas, em 30 de abril de 2004. Com a liderança militar brasileira, essa operação iniciou, como explica Rodrigues (2013, p. 149), uma nova prática não relacionada à resolução de uma guerra civil entre forças ou de apoio militar na transição de um conflito:

A MINUSTAH trouxe uma combinação de autorizações previstas nos capítulos VI e VII da Carta de S. Francisco, incorporando simultaneamente as prerrogativas de manter e de impor a paz - usar força coercitiva - além de todo o vasto objetivo de construção político-institucional. (RODRIGUES, 2013, p. 149).

Dentro do contexto do conceito de segurança humana, abordado anteriormente, a MINUSTAH faz parte das denominadas operações de paz multidimensionais, ou de estabilização. Essa nova modalidade de operação tem o objetivo de reestruturar ou estruturar as polícias, prover assistência humanitária, assegurar o respeito aos ditos direitos humanos,

\footnotetext{
${ }^{14}$ Segundo Corbellini (2009, p. 81), acompanhando a complexidade dos conflitos da Guerra Fria (principalmente em seu final), as operações de manutenção da paz estiveram em constante transformação. Essas operações foram oficializadas no documento Diretrizes Gerais para as Operações de Manutenção da Paz, de autoria da ONU, que determina os princípios de atuação, assim como a ajuda humanitária.

${ }^{15}$ Capítulo que trata das ações relativas a ameaças à paz, ruptura da paz e atos de agressão. Destacam-se os Artigos 39 e 42 que estipulam que o Conselho de Segurança determinará a existência de ameaças à paz, ruptura da paz e atos de agressão, bem como as medidas a serem tomadas para restabelecer a dita segurança internacional, incluindo o uso das forças aéreas, terrestres ou navais.
} 
organizar eleições, estabelecer ou restabelecer governos democráticos, promover a reconstrução econômica e o desenvolvimento do país e de criar comissões de reconciliação entre grupos opositores (CORBELLINI, 2009, p. 80).

Para as operações serem estabelecidas, a partir dos anos 1990, os riscos à segurança internacional foram ampliados para uma série de fatores como terrorismo, multiplicação de armas de destruição em massa e crises humanitárias, diferentemente do período da Guerra Fria, cujo principal fator de ameaça eram situações que comprometiam a integridade territorial dos Estados.

Ao analisar os objetivos do primeiro mandato da MINUSTAH, expressos na Resolução 1542 (2004), apontaremos os diferentes mecanismos de governo que atravessam tal missão. De acordo com Foucault (2005, p. 288), explicando a lenta e gradual transformação no direito político a partir do século XVI, no seu curso "Em defesa da sociedade", o autor aponta que os séculos XVII e XVIII viram emergir tecnologias de poder centradas no corpo individual, pelas quais tentavam aumentar suas forças com exercícios e treinamentos, além de estabelecer todo um sistema de vigilância e hierarquias, o que Foucault chamou de tecnologia da disciplina do trabalho. A partir da segunda metade do século XVIII, há a emergência de uma nova tecnologia de poder, a biopolítica. Esta não substitui a técnica disciplinar, pois está em outra superfície de suporte, auxiliada por instrumentos completamente diferentes, em outra escala, outro nível.

Enquanto a disciplina se encarrega dos corpos individuais, a biopolítica trata da multiplicidade dos homens como massa global, afetada por fenômenos próprios da vida como nascimento, morte, doença etc. Tais fenômenos introduzem uma medicina que terá função maior da higiene pública, da centralização da informação, da normalização do saber, bem como a medicalização da população. Outro campo de intervenção da biopolítica tratará de fenômenos universais e acidentais como a velhice - o indivíduo que sai da capacidade de atividade - e as doenças e anomalias diversas. Ou seja, a biopolítica se dirigirá aos acontecimentos aleatórios em um elemento que emerge nesse contexto, a população (FOUCAULT, 2005, p. 293).

A biopolítica vai utilizar-se de mecanismos muito diferentes da disciplina: 


\begin{abstract}
Nos mecanismos implantados pela biopolítica, vai se tratar, sobretudo, é claro, de previsões, de estimativas estatísticas, de medições globais; vai se tratar, igualmente, não de modificar tal fenômeno em especial, não tanto tal individuo, na medida em que é individuo, mas, essencialmente, de intervir no nível daquilo que são as determinações desses fenômenos gerais, desses fenômenos no que eles tem de global. (FOUCAULT, 2005, p. 293).
\end{abstract}

Assim como os mecanismos da disciplina, a gestão biopolítica de tais fenômenos será para maximizar as forças da população, porém, por caminhos diferentes. Não significa o cuidado com o detalhe, no nível do individuo, mas por mecanismos globais, agir para obter estados globais de equilíbrio. Trata-se de assegurar sobre a população não uma disciplina, mas uma regulamentação (FOUCAULT, 2005, p. 294).

Existem, portanto, a partir do século XIX, duas séries de mecanismo, sendo uma sobre o corpo e as instituições - disciplina - e outra sobre a população e o Estado - a biopolítica. Ainda, embora estejam em planos distintos, esses mecanismos podem incidir simultaneamente sobre o corpo e a população, como é o caso da sexualidade e da medicina. A sexualidade enquanto um comportamento depende de um controle disciplinar individual, entretanto, ela também, devido ao processo biológico que a envolve, adquire efeitos regulamentadores. Tal qual a medicina, um saber-poder que incidirá sobre o processo biológico e sobre o corpo.

Sendo assim, como não existe a era do legal, a era do disciplinar e a era da segurança, destacaremos os objetivos da missão correlacionando os mecanismos de governo - seja em nível de população, seja em nível de indivíduo - não como elementos separados, mas como estruturas que fazem funcionar uma a outra com maior eficiência, uma vez que Foucault não trabalha pela lógica hegeliana da negação da negação, mas sim pela descontinuidade, que Deleuze entende como o acoplamento de diferentes técnicas de poder. Além disso, Foucault (2005, p. 302) nos dirá que a análise de uma sociedade de normalização apenas em termos de disciplina é insuficiente.

Em nível de regulação da conduta estatal, podemos observar o dispositivo de polícia, e a estatística como instrumento, no conceito de Estado Falido - outro indicador determinante para apontar uma ameaça à segurança internacional. Esse conceito foi formulado para designar Estados incapazes de atender e preservar os direitos dos seus cidadãos. Um dos meios para 
definir a falência estatal é o índice anual publicado no periódico Foreign Policy que expõe alguns indicadores como pressões demográficas, movimento massivo de refugiados ou pessoas deslocadas internamente, fuga humana, desenvolvimento econômico, criminalização ou deslegitimação do Estado, intervenção externa, violação dos direitos humanos, dentre outros. Após levantar os dados de cada um dos indicadores, o periódico atribui uma nota de 0 (mais estável) a 10 (menos estável) a cada um deles, sendo a soma total ( 0 a 120) a definição sobre a falência. Em 2005, O Haiti teve a soma de suas notas em um total de $99,2^{16}$ pontos, figurando entre os 10 países mais instáveis e vulneráveis. Outros países da América Latina possuíam somas altas, tais como Venezuela $(93,5)$ e República Dominicana $(94,2)$. Em 2017 ${ }^{17}$, ano de término da Minustah, o Haiti possuía a pontuação de 105,3. Ou seja, a partir do levantamento de estatísticas, a polícia faz saber não só a condição interna de cada Estado, como também o uso de sua soberania.

Dentre os objetivos do primeiro mandato da MINUSTAH, continuamos a destacar aqueles que demandam preocupação com a conduta do Estado haitiano como, por exemplo,

\begin{abstract}
Apoiar o processo constitucional e político em curso no Haiti, por meio de princípios de governo democrático e desenvolvimento institucional; ajudar o governo de transição na tarefa de organizar, supervisionar e realizar eleições municipais, parlamentares e presidenciais livres e justas. (UNITED NATIONS, 2004).
\end{abstract}

Além disso, a Resolução também propõe a criação de instituições próprias a Estados liberais ${ }^{18}$. Nesse caso, o biopoder, uma vez que não se trata do indivíduo, produz uma conduta ${ }^{19}$, um modelo, de Estado tendo por fim o governo da população.

Todavia, a disciplinarização ${ }^{20}$, a regulamentação no nível do indivíduo, é também um elemento central nessa missão da ONU e aponta para um acoplamento com os mecanismos de segurança, pois, para Foucault (2008, p. 433), a segurança faz funcionar a estrutura disciplinar.

\footnotetext{
${ }^{16}$ Disponível em: <https://foreignpolicy.com/2009/10/22/the-failed-states-index-2005/.> Acesso em: 06/07/19.

${ }^{17}$ Disponível em: <https://fragilestatesindex.org/analytics/fsi-heat-map/> Acesso em: 06/07/19.

18 Disponível em: 〈http://www.un.org/en/ga/search/view_doc.asp?symbol=S/RES/1542(2004)> Acesso em: 06/07/19.

${ }^{19}$ De acordo com Rodrigues (2013, p. 151).

${ }^{20} \mathrm{O}$ processo de disciplinarização, conforme explica Castro (2004, p. 133), trata, dentre outras coisas, de ampliar os mecanismos disciplinares.
} 
Além de difundir os mecanismos disciplinares, ao propor "a manutenção do Estado de direito, segurança pública e ordem pública” (UNITED NATIONS, 2004, p.1), a MINUSTAH tinha por objetivo garantir seu bom funcionamento "reestruturando e reformando a polícia nacional haitiana de acordo com os padrões de policiamento democrático" (UNITED NATIONS, 2004, p.1). Ou seja, impondo um modelo de instituições e governança ao Estado (segurança) e estatizando os mecanismos disciplinares, a polícia (disciplinarização).

A regulação dos indivíduos é vista na promoção do chamado programa de Desarmamento, Desmobilização e Reintegração (DDR), outro objetivo da missão. Conforme Corbellini (2009, p. 104), esse programa foi desenvolvido para desmobilizar e desarmar grupos rebeldes, assim como para reintegrar os ex-combatentes na sociedade. Para tanto, a ONU dedicou um artigo ao DDR no Relatório de Brahimi ${ }^{21}$ para afirmá-lo como ponto-chave para a manutenção da estabilidade pós-conflito. Ademais, no relatório "nossa responsabilidade compartilhada ${ }^{22}$ " de 2004, a Organização afirma que não implementar tal programa resultaria em desemprego dos jovens e o retorno destes para as gangues. A reintegração resulta em capacitar os ex-combatentes e suas famílias para o mercado de trabalho, além de oferecer uma série de compensações financeiras.

A partir de Foucault (2002, p. 113), é possível perceber a função disciplinar da reintegração:

\begin{abstract}
Nas instituições que se formam no século XIX não é de forma alguma na qualidade de membro de um grupo que o indivíduo é vigiado; ao contrário, é justamente por ser um individuo que ele se encontra colocado em uma instituição, sendo esta instituição que vai constituir o grupo, a coletividade que será vigiada. É enquanto indivíduo que se entra na escola, que se entra no hospital, ou na prisão. Estas não são formas de vigilância do próprio grupo. É a estrutura de vigilância que, chamando para si os indivíduos, tomando-os individualmente, integrando-os, vai constituí-los secundariamente enquanto grupo (FOUCAULT, 2002, p. 113).
\end{abstract}

Ou seja, mesmo que as instituições - fábrica, escola, prisão, hospital - gerem a exclusão, elas têm como primeira finalidade fixar os indivíduos em um aparelho de normalização dos

\footnotetext{
${ }^{21}$ Disponível em: https://www.un.org/en/events/pastevents/brahimi_report.shtml Acesso em: 06/07/2019.

${ }^{22}$ Disponível em: https://www.un.org/en/events/pastevents/a_more_secure_world.shtml Acesso em: 06/07/2019.
} 
homens e por objetivo ligar o indivíduo a um processo de produção, de formação ou de correção (FOUCAULT, 2002, p. 114).

Como em todo sistema disciplinar funciona um pequeno mecanismo penal (FOUCAULT, 1987, p. 194), a ONU desenvolveu o Tribunal Penal Internacional - corte internacional, estabelecida em 2002, que julga crimes "contra a humanidade". Segundo Rodrigues (2013, p. 150), a força corretiva sobre as condutas de indivíduos se estende para além da punição aos culpados, mas sem abdicar dela. Não se trata, no entanto, de dizer que a MINUSTAH inventou os mecanismos disciplinares no Haiti, mas os modelou e os impulsionou.

No decorrer da missão sua faceta militar ganhou maior protagonismo. As recorrentes operações militares pelas periferias haitianas geraram um total de mais de 30 mil $^{23}$ mortos, ao fim dos 13 anos da missão. Porém, como um governo que deve fazer viver, promover os ditos direitos humanos, pode provocar a morte de tantos haitianos? Por meio do racismo. Foucault (2005, p. 307) nos dirá que, tendo por objeto e objetivo a população, o racismo é utilizado para suprimir os perigos internos e externos da e para a população. Por isso, e pela relação biológica, a função assassina do Estado é garantida pelo biopoder e pelo racismo. Por assassínio também se entende o seu sentido indireto como expor à morte, multiplicar para alguns o perigo de morte ou a morte política, como rejeição e expulsão.

\section{A MINUSTAH e o assento permanente do Brasil no Conselho de Segurança das Nações Unidas}

O convite ao Brasil para participação na MINUSTAH resultou em muitas possibilidades de análises acerca dos interesses brasileiros nessa operação. Dentre os interesses, salientaramse a busca por notoriedade internacional, que permeou a política externa brasileira ao longo do século e também no decorrer dos sessenta anos de operações de paz da ONU, e a busca por um assento permanente no Conselho de Segurança das Nações Unidas (CSNU).

23 Disponível em: <https://www.brasildefato.com.br/2017/09/01/estupros-colera-e-30-mil-mortos-conheca-olegado-da-minustah-no-haiti>. Acesso em: 06/07/19. 
Apesar de ser apenas o $18^{\circ}$ país ${ }^{24}$ a contribuir com militares e tropas para as missões de paz, o Brasil participou em quase todas as operações no planeta. A primeira participação do país em missões de paz da ONU - houve participações antes mesmo da criação desse organismo internacional - foi na UNSCOB (Comitê Especial das Nações Unidas para os Bálcãs), durante a crise dos Bálcãs, em 1947, com envio de militares. Entre os anos de 1957-1967, o país enviou tropas na composição da UNEF I (Forças de Emergência das Nações Unidas). As tropas brasileiras auxiliaram França, Inglaterra e Israel no conflito com o Egito, que havia nacionalizado o Canal de Suez e administrava a Faixa de Gaza - invadida por Israel durante tal operação. Segundo Mathias e Pepe (2006, p. 4), essa foi a primeira grande participação do país em operações de paz.

Durante o período de intervenção na UNEF I, o Brasil ainda participou de duas missões: a ONUC (Operação das Nações Unidas no Congo), entre 1960-1963, e a UNSF (Força de Segurança das Nações Unidas na Nova Guiné Ocidental), em 1962. Ambas como partes de construção de uma Política Externa Independente dos Presidentes Jânio e Goulart. Além da UNEF I, o Brasil participou de outras duas operações da ONU durante a Ditadura Militar, na Força das Nações Unidas no Chipre (UNFICYP), entre 1964-1974, e na FAIBRÁS (Força Interamericana) na República Dominicana, em 1965.

No período após a redemocratização, o país retoma as participações em operações da Organização buscando um papel mais destacado no cenário internacional (MATHIAS e PEPE, 2006, p. 7). Até o governo Lula da Silva, o país participou de mais de 10 operações ao redor do mundo, principalmente nas ex-colônias portuguesas.

Apesar de todas essas participações, o Brasil sempre contribuiu apenas enviando oficiais de ligação ou de Estado Maior, principalmente como observadores militares. Todavia, apenas em três ocasiões - Angola, Moçambique e UNEF I - o país enviou o comandante da força. Kenkel (2011, p. 16) explica que o país aderiu rigorosamente à norma de não intervenção (exposta na Constituição Federal de 1988), interpretada como a proibição de qualquer

\footnotetext{
24 Ranking até 2008, quando Lula ainda era presidente. Disponível em: www.un.org/Depts/dpko/dpko/contributors/2008/apr08 2.pdf Acesso em: 30/07/2019.
} 
participação em missões, exceto aquelas descritas no Capítulo VI ${ }^{25}$ da Carta da ONU, sendo o Capítulo VII entendido pela diplomacia brasileira como uma violação do seu Artigo $2^{\circ}$ (KENKEL, 2011, p.25).

Crítico às operações baseadas no Capítulo VII, o Brasil, como membro não permanente do Conselho de Segurança em 1994, optou por não manifestar seu voto em inúmeras resoluções sobre o Haiti - na época, ocupado pela UNMIH (Missão da ONU no Haiti, iniciada em 1993) -, além de ter-se abstido na votação sobre a implementação de uma operação mais "robusta" em Ruanda, por não seguirem o princípio da não interferência (KENKEL, 2011, p. 23).

Essas participações em operações anteriores, como também a fidelidade ao princípio da não interferência e ao apoio somente às operações baseadas no Capítulo VI da Carta da ONU, são importantes para analisarmos as motivações que levaram ao envio de tropas ao Haiti, em 2004.

A história do país com o assento no Conselho de Segurança vem desde a fundação da ONU. O Brasil ocupou assento não permanente já na primeira formação do CSNU, ademais, reivindicou no primeiro ano assento permanente. Entretanto, teve sua reclamação negada por Inglaterra e União Soviética. A atuação do Brasil no CSNU continuou: nos primeiros 22 anos da Organização (1946-1968), o país foi membro não permanente por 10 anos. Após a redemocratização, foi membro não permanente em 1988-1989, 1993-1994 e 1998-1999.

Foi na década de 1990 que o Brasil, pensando na possibilidade de haver uma reforma nos quadros da ONU devido ao fim da Guerra Fria, retoma a sua campanha para reivindicar um assento permanente no CSNU. Todavia, tal pleito, explica Diniz (2005, p. 95), estaria prejudicado devido à diminuição da participação brasileira nas operações das Nações Unidas, principalmente no final dos anos de 1990, quando se intensifica a participação do Brasil no CSNU.

A participação brasileira na MINUSTAH difere da história da diplomacia nacional no CSNU e nas operações da ONU - as ações anteriores à entrada no Haiti eram baseadas no

\footnotetext{
${ }^{25}$ O Capítulo VI da Carta da ONU determina, em seu Artigo 33, que as partes em conflito - conflito este que possa ameaçar a segurança internacional - deverão, antes de tudo, encontrar soluções por meio da negociação, conciliação ou qualquer outro meio pacífico, sendo o Conselho de Segurança um órgão mediador. O Capítulo VII já admite a possibilidade do uso da força para "imposição da paz".
} 
capítulo VI da Carta das Nações Unidas - e se contradiz com a Constituição Federal (1988), que determina o princípio da não interferência em caso de participação brasileira em Missões de Paz. A missão no Haiti é baseada no Capítulo VII - que inclui o uso de forças armadas para resolução de conflitos internacionais. Entretanto, ao mesmo tempo em que vai contra o princípio de não interferência, até então unânime, a Missão surge em um momento propício para ganhar autonomia internacional e aumentar prestígio para o almejado assento permanente no CSNU.

Embora o princípio da não interferência esteja exposto em outras matrizes, o texto - a Constituição Federal de 1988 - que fundamenta a participação brasileira em Missões de Paz permite diferentes interpretações conforme os interesses políticos (KENKEL, 2011, p. 17). O Artigo $4^{\circ}$ da Constituição elenca inúmeros princípios da ação internacional do Brasil, como independência nacional, prevalência dos direitos humanos, não intervenção, defesa da paz e repúdio ao terrorismo e ao racismo.

Esses interesses divergentes aos princípios fazem surgir, segundo Corrêa (2009, p. 47), um novo paradigma nas operações de paz no discurso oficial brasileiro. Para justificar a participação em uma operação que se baseia no Capítulo VII, o então Presidente Lula e seu Ministro das Relações Exteriores Celso Amorim afirmam que a atuação brasileira vai para além da esfera da segurança, pois é motivada "pela solidariedade e pela crença na possibilidade de desenvolver uma nova esperança de paz e justiça nos irmãos haitianos” (SILVA, 2005, p. 1). Celso Amorim defendia que a ação do Brasil estava voltada a uma orientação multidimensional, ou seja, pensava-se na reconciliação política e, sobretudo, no desenvolvimento econômico do Haiti, além da segurança. A ação brasileira estaria movida por uma diplomacia da generosidade e solidariedade, na qual criaria um novo paradigma para as operações de paz. (CORRÊA, 2009, p. 90).

Em 2004, durante reunião da Comissão de Relações Exteriores ${ }^{26}$, o Ministro Celso Amorim salientou o desejo do país de desenvolver outros projetos no Haiti além do militar,

\footnotetext{
${ }^{26}$ Comissão estabelecida no Senado após o Presidente Lula enviar mensagem explicitando o desejo de participar da MINUSTAH. A Comissão tinha por objetivo discutir a viabilidade do envio de tropas para o Haiti.
} 
como a reestruturação da infraestrutura, conforme levantado por Gonçalves (2011, p. 65). Afirmou também que, por ambos os países terem passado por um processo de colonização e possuírem uma grande população negra, a missão estabeleceria uma relação de país-irmão.

Conforme Corrêa (2009, p. 87), algumas medidas foram tomadas pelo Brasil não relacionadas à segurança, como a doação de comidas e brinquedos feita por militares e a reconstrução de estradas pelo Contingente de Engenharia da Força de Paz. Entretanto, o autor salienta que não encontrou

Nenhum tipo de dado que pudesse dar respaldo a um possível modus operandi brasileiro ou latino americano menos violento nas ações estritamente militares. Os dados levantados pelos mencionados relatórios ${ }^{27}$ sobre violações dos direitos humanos apontam inclusive para uma direção oposta, ou seja, de que existem indícios de momentos de exacerbação do uso da força por parte das tropas. (CORRÊA, 2009, p. $88)$.

O Brasil guiou sua atuação a partir do Quadro de Cooperação Interamericana (ICF), mesmo não participando da reunião que elaborou o inventário. O ICF foi criado em 2004 e financiado por Nações Unidas, Banco Mundial, Banco Interamericano de Desenvolvimento e Comissão Europeia, tendo como objetivo definir os principais pontos a serem desenvolvidos por uma ação internacional no Haiti. O Banco Interamericano e o Banco Mundial também financiaram o inventário Emergency Economic Recovery Program, criado em 1995, que baseou a atuação estadunidense na UNMIH. Ambos os projetos (MINUSTAH e UNIMIH), além de financiados pelas mesmas instituições, elencam os mesmos objetivos - ajuda humanitária, estímulo ao crescimento econômico, construção da democracia, controle populacional e proteção à saúde - sendo o projeto brasileiro nada inovador (CORRÊA, 2009, p. 60-65).

Ao não ser eficiente em propor novos objetivos de uma possível diplomacia solidária, os usos políticos da ocupação ficam ainda mais evidente. A busca por protagonismo internacional está inteiramente ligada à busca pela reforma no Conselho de Segurança, como apontam Mathias e Pepe (2006, p. 16):

\footnotetext{
${ }^{27}$ Relatórios produzidos pela Amnesty International, em 2005, e pela Justiça Global, em 2007. Disponível em: www.amnesty.org/en/library/info/AMR36/005/2005 e www.global.org.br/haitiportuguese.pdf Acessados em: $30 / 07 / 2019$
} 


\begin{abstract}
Assim, a participação em operações de paz da ONU vem sendo encarada como condição importante para a obtenção de uma vaga permanente no Conselho. Participar delas, entende o governo brasileiro, é uma forma de demonstrar capacidade de assumir grandes responsabilidades e de estar interessado em desempenhar papel de relevo nas questões prementes da agenda internacional (MATHIAS e PEPE, 2006, p.16).
\end{abstract}

Portanto, o envio de tropas brasileiras para o Haiti faz emergir questões quanto aos interesses do país nesta Missão, uma vez que se contrapõem aos princípios referentes às ações internacionais expressos na Constituição Federal de 1988 e tampouco condizem com o histórico de participações brasileiras em operações de paz ao longo do século XX e desde a criação da ONU. Sobretudo com a redemocratização do país, ficou mais evidente a incompatibilidade da diplomacia brasileira às missões baseadas no Capítulo VII da Carta da ONU - o que gerou a diminuição da participação do Brasil em operações da Organização na década de 1990.

\title{
Considerações finais
}

A MINUSTAH representou o ápice do permanente estado de vigilância ao que o Haiti país tem estado submetido - desde a Revolução (1791-1804), a qual justificou as sucessivas intervenções externas nos processos políticos do país. Sob o pretexto da segurança humana e com caráter de legalidade, a nova operação multidimensional da ONU esteve comprometida em atingir estruturas para além da dimensão militar. Tratando da multiplicidade dos homens - a população - a missão definiu como objetivos principais formar instituições próprias ao regime político democrático liberal e reformular as polícias. Ademais, direcionando-se aos corpos individuais, a Organização das Nações Unidas também inseriu o programa de Desarmamento, Desintegração e Reintegração (DDR) nos objetivos da operação. Ou seja, dessa forma, a MINUSTAH articulou técnicas de governo biopolíticas e disciplinares para gerir o país caribenho, prescrevendo condutas de indivíduos e do Estado haitiano.

A Revolução haitiana, protagonizada por negros que aniquilaram a presença colonial na ilha, estava no contexto da emergência da população, entendida esta como uma técnica de governo (FOUCAULT, 2008, p. 56). Todavia, quando se trata do Haiti, a dicotomia 
povo/população fica evidente. Uma diferença conceituada por Foucault utilizando o exemplo da administração da escassez alimentar na França do século XVIII, e as ideias do fisiocrata Abeille, ao entender que mesmo dentro do modelo de liberdade total pregado pela nascente sociedade capitalista poderia ainda ocorrer revoltas e que aqueles que se revoltassem não pertenciam realmente à população. O que seriam?

\footnotetext{
Pois bem, são o povo. O povo é aquele que se comporta em relação a essa gestão da população, no próprio nível da população, como se não fizesse parte desse sujeitoobjeto coletivo que é a população, como se se pusesse fora dela, e, por conseguinte, é ele que, como povo que se recusa a ser população, vai desajustar o sistema. (FOUCAULT, 2008, p. 56).
}

E continua: "vemos estabelecer-se uma divisória na qual o povo aparece como sendo, de uma maneira geral, aquele que resiste à regulação da população, que tenta escapar desse dispositivo pelo qual a população existe, se mantém, subsiste, e subsiste num nível ótimo" (FOUCAULT, 2008, p. 58).

As grandes potências ocidentais, sempre a posto para intervir, com seu fuzil de ombro, em território haitiano, não satisfeitas ao impor - pós-Independência - o assassínio indireto e utilizarem-se do dispositivo de polícia ao longo do século XX, atualizaram e reorganizaram suas técnicas de governo para mais uma vez tentar controlar os rumos desse país, porém, dessa vez, contando com o apoio de vizinhos latino-americanos, como o Brasil, que mesmo tendo sido objeto por vezes do intervencionismo estrangeiro, agiram em prol de seus próprios interesses políticos.

Entretanto, o Haiti, mais uma vez, atravessou tal processo e segue, em nível de população, agindo como povo. Atualmente, dois anos após as tropas da ONU deixarem o país, as ruas estão tomadas de manifestantes que pedem, depois de derrubarem o Primeiro-Ministro, a renúncia do Presidente. Um país com sua própria maneira de funcionar que insiste em resistir às sucessivas intervenções.

Portanto, entendemos o Haiti como povo. Desde sua independência, quando estabeleceu uma república negra em uma América escravocrata e influenciou sua metrópole européia a abolir a escravidão, o Haiti já se recusava a regular-se pelos dispositivos que governam uma 
população. Um país que resistiu, também, durante todo o século XX e segue construindo possibilidades de existência frente a um Ocidente atravessado pela biopolítica.

\section{Referências Bibliográficas:}

ANTONIN, Arnold. "Haití: La enesima crisis electoral”. Buenos Aires: Nueva Sociedad, Edición Especial, 2006.

BBC. A multa astronômica que um dos países mais pobres do mundo teve de pagar por sua independência. Brasil, 2019. Disponível em <www.bbc.com/portuguese/amp/internacional46721129>. Acesso em: 06/07/2019.

BRASIL. Constituição Federal de 1988. Brasília: Congresso Nacional, 1988. Disponível em: <http://www.v-brazil.com/government/laws/titleI.html>. Acesso em: 06/07/2019

Ministério da Defesa. Política de Defesa Nacional. Brasília, 1996. Disponível em: <http://merln.ndu.edu/whitepapers.html>. Acesso em: 06/07/2019.

.Política de Defesa Nacional. Brasília, 2005. Disponível em: <http://merln.ndu.edu/whitepapers.html>. Acesso em: 06/07/2019.

CAJOU, Pierre Philippe. O processo de democratização do Haiti e suas limitações. 2013.

CASTOR, Suzy. El reto de una nueva policía. Nueva Sociedad, Buenos Aires 1995. La ocupación norteamericana de Haití y sus consecuencias (1915-1934). Santo Domingo: Fundación Juan Bosch, 2016.

. Haití: de la ruptura a la transición. Nueva Sociedad, n. 82, p. 54-63, 1986.

. El significado histórico de la Revolución de Saint-Domingue. Archipuelago, Revista cultural de nuestra América, v. 11, n. 43, 2004.

CASTRO, Edgardo. El Vocabulario de Michel Focault. Buenos Aires: Prometeo, 2004.

CHARLES, Gérard Pierre. Crisis del Estado e intervención internacional en Haiti. Revista Venezolana de Economia y Ciencias Sociales, vol. 10, n. 3, p. 233-242, 2004.

. Radiographie d'une dictature. Montréal: Nouvelle Optique, 1973.

Haití: nuevas etapas de la resistencia popular. Nueva Sociedad, v. 73, p.18-

$21,1984$. 
CORBELLINI, Mariana Dalalana. Haiti: da crise ao Minustah. 2009.

CORREA, Paulo Gustavo Pellegrino. MINUSTAH e a diplomacia solidária: um novo paradigma nas operações de paz? 2009.

DINIZ, E. O Brasil e a MINUSTAH. Mimeo: CHDS, 2005.

FICK, Carolyn E. Haiti. Naissamce d'une nation. La Révolution de Saint-Domingue vue d'en bas. Bayeux: Les Perséides, 2014.

FOUCAULT, Michel. Segurança, território, população. São Paulo: Martins Fontes, 2008. . Em defesa da sociedade. São Paulo: Martins Fontes, 2005. . A verdade e as formas jurídicas. Rio de Janeiro: NAU Editora, 2002. . Vigiar e punir. Petrópolis: Vozes, 1987.

GARCIA, Eugenio Vargas. O Brasil e a Liga das Nações (1919-1926): Vencer ou não perder. Porto Alegre: Editora da Universidade, Universidade Federal do Rio Grande do Sul, 2000.

GONÇALVES, Israel Aparecido. A repercussão pública da participação do Brasil na Minustah. 2011.

KENKEL, Kay. "Interesses e identidades na participação do Brasil em operações de paz". Revista Tempo do Mundo, v. 3, n. 2, p. 9-33, 2011.

MATHIAS, Suzeley Kalil; PEPE, Leandro Leone. Segurança e democracia: a atuação do Brasil no Haiti. Março de, 2006.

RIBEIRO, Manuel de A.; FERRO, Monica. A Organização das Nações Unidas. Coimbra: Livraria Almedina, 2004.

RODRIGUES, Thiago. Ecopolíticna e segurança: a emergência do dispositivo diplomáticopolicial. São Paulo, Revista Ecopolítica. n. 5, p. 115-156, 2013.

SILVA, Luís Inácio Lula da. Discurso do Presidente Luís Inácio Lula da Silva durante a sessão de abertura da XVI Conferência de Chefes de Governo da Comunidade do Caribe, Caricom, 2005. 
UNITED NATIONS. United Nations Security Council. Resolution 1542 (2004). Disponível em: <http://www.un.org/en/ga/search/view_doc.asp?symbol=S/RES/1542(2004)>. Acesso em: 06/07/2019.

VIZENTINI. Paulo G. V. Do Nacional-Desenvolvimentismo à Política Externa Independente. In: FERREIRA, Jorge \& DELGADO, Lucilia de Almeida Neves (Org.). $O$ Brasil Republicano O tempo da experiência democrática Da democratização de 1945 ao golpe civil-militar de 1964. Rio de Janeiro: Civilização Brasileira, 2003. 